\title{
Research of Production and Growth of Coriander in Various Seasons using K-Means Algorithm
}

\author{
N.Santhosh, R.Shankar, R.Narendranath, K.Srinivasan
}

\begin{abstract}
The main employment and resource of our country is agriculture. In the upcoming days agriculture is going to be one of the important field .Agriculture plays a vital role in economical development of india. Half of the Indian population is mainly depended on agriculture. It is the source of living it is important in everyday life. Comparing to previous years Now-aday's Agriculture is in poor condition. The most important reasons for this is there is no proper guidance for the farmers.Outstanding to these problems, farming affects the yield of Coriander and lack of knowledge about the Coriander cultivation methodologies. And also season to cultivate the coriander and choosing which soil is the best to cultivate the particular Coriander based on the weather condition and also when to harvest the Coriander for the best yield. If the farmer is aware about the Coriander cultivation methodologies and harvesting it will more helpful for the people in the real world and also to increase the Coriander productivity. Data mining is the process of finding new template from large data sets, this technology which is in use in inferring useful knowledge that can be put to use from a vast amount of data. Climate is one of the meteorological data that is well-to-do by important knowledge.

This paper presents a brief comparative study of various different techniques used for yield of coriander. The data mining techniques that are in use for the coriander yield estimation are K-Means.
\end{abstract}

Keywords: coriander yield, Data mining, K-Means.

\section{INTRODUCTION}

Coriander is called as important spice crop. The extra flavour to the food can be added with coriander. The coriander is thin stemmed plant.It consists of very small, bushy herb with the height of 25 to $50 \mathrm{~cm}$ with many branches .coriander consists of the alternate and compound leaves. The coriander Fruit has 3 to $4 \mathrm{~mm}$ diameter. when the fruit is pressed it breaks into two locules each locules have one seed. The fruit has very nice fragrance; the seeds are light brown to pale white in colour. There are 9 types of coriander in India but there are only three types are mostly used for profitable cultivation. Now-a-days it plays a critical role and has a poor condition comparing with earlier year cultivation, because without a well formed modeling and pattern for farming. There is no proper guidance to farmer about the weather change and to choose the best soil. If the

Revised Manuscript Received on September 14, 2019.

N.Santhosh, Student, Department of Computer technology, Sri Krishna arts \& science College, Coimbatore, Tamilnadu, India.(E-mail: santhoshn18mct010@skasc.ac.in)

R.Shankar, Assistant Proffessor, Department of Computer technology, Sri Krishna arts \& science College, Coimbatore, Tamilnadu, India.(E-mail: shankarr@skasc.ac.in)

R.Narendranath, Department of Computer technology, Sri Krishna arts $\&$ science College, Coimbatore, Tamilnadu, India.

K.Srinivasan, Department of Computer technology, Sri Krishna arts \& science College, Coimbatore, Tamilnadu, India. farmer is well known about the weather, soil to cultivate it increases the yield in real world. Data mining is the process of finding new pattern from huge data sets, this technology which is in use in inferring useful knowledge that can be put to use from a huge amount of data.

\section{BOTANCIAL/SCIENTIFIC CLASSIFICATION}

Common name:

Genus: Coriandrum L. - coriander P

Species: Coriandrum sativum L. - coriander P

Family: Apiaceae

Kingdom: Plantea

Types of coriander: 9 (In India)

\section{PROBLEM DEFINITION}

The problem defined here is agriculture data analysis in crop yield estimation a critical review, climate and soil Climate and soil plays the important role in agriculture crop yield estimation. The coriander grows in the Well drained silt or loamy soils which are suited for coriander cultivation. The soils $\mathrm{pH}$ should be $6-8$ and clay in nature for the rainfed cultivation. The $20-25{ }^{\circ} \mathrm{C}$ is the perfect temperature for growing coriander. Thermometer is used to measure the climate. Tensiometer is a measuring instrument .It is used to determine the matric water potential. The yield estimation of the coriander is calculated using the Data mining algorithm. The specified data mining algorithm used here is K-Means Clustering Algorithm. It is used to separate the data into different clusters containing points with similar characteristics.

\begin{tabular}{|c|c|c|}
\hline Climate & Temperature & Month \\
\hline Winter & $\begin{array}{l}\text { Temperature } \\
\text { should be below } 5 \\
\text { degree }\end{array}$ & $\begin{array}{l}\text { January } \\
\text { February }\end{array}$ \\
\hline Summer & $\begin{array}{l}\text { temperatures of } 55 \\
\text { to } 68 \text { degrees }\end{array}$ & March to may \\
\hline $\begin{array}{l}\text { Advanced } \\
\text { Monsoon }\end{array}$ & $\begin{array}{l}\text { Average of } 20 \text { to } \\
25 \text { degree }\end{array}$ & $\begin{array}{l}\text { June } \\
\text { September }\end{array}$ \\
\hline Post-Monsoon & $\begin{array}{l}\text { Temperature not } \\
\text { less than } 30 \text { to } 35\end{array}$ & $\begin{array}{ll}\text { October } & \text { to } \\
\text { December } & \end{array}$ \\
\hline
\end{tabular}

Published By: 


\section{MAJOR PROBLEMS IN GROWING CORIANDER LEAVES}

1. Weather Conditions

2. Soil

3. Fertilizing

\section{WEATHER}

Coriander is a tropical crop and it is also called as an rabi crop. The sowing is done in the middle of October to November- end. It takes 4-6 irrigations. The two main crops are kharif ,soybean and paddy.

Crop period of coriander is between 110-140 days it is harvested in February to March. The matured Seeds looks in yellowish green when the crop is harvested it looks dried in the green colour. Mostly to avoid breakage coriander are cut early in the morning. graded and sieves are used to clean the seeds. Under rain fetch condition the yield of coriander is about $500-600 \mathrm{~kg}$ and during irrigation 1200 $2000 \mathrm{~kg}$.Coriander is mainly a winter crop and can grown in all other seasons also. Coriander gets mainly affected due to heavy rain. Cool and frost free climate is suitable for coriander cultivation.

\begin{tabular}{|c|c|c|}
\hline NAME OF THE DISEASE & CAUSES \& SYMPTOMS & PRECAUTIONARY METHODS \\
\hline Bacterial leaf spot & $\begin{array}{l}\text { between leaf veins water soaked } \\
\text { spots is noted. which slowly turns from } \\
\text { dark brown to black. Dark streaks is } \\
\text { noted on the stems looks like yellow } \\
\text { and slowly turns into brown colour. }\end{array}$ & $\begin{array}{l}\text { It is very difficult to control but } \\
\text { plantation of pathogen free seeds may } \\
\text { help.do not do overhead irrigation and } \\
\text { avoid working with wet plants. }\end{array}$ \\
\hline Soft rot & $\begin{array}{l}\text { Petioles becomes soft near water } \\
\text { soaked lesion.it is mainly caused by } \\
\text { bacteria looks brown in colour. }\end{array}$ & $\begin{array}{l}\text { Precautionary measures should be } \\
\text { done to avoid bacterial infections. } \\
\text { Coriander should be planted in well } \\
\text { drained soil. Kindly avoid the wounded } \\
\text { plants. }\end{array}$ \\
\hline Carrot motley dwarf & $\begin{array}{l}\text { Sudden dropeage in plant growth } \\
\text { Leaves looks yellow and red in colour. } \\
\text { Aphids is the main reason for } \\
\text { transformation of disease }\end{array}$ & $\begin{array}{l}\text { Closely and tight plantation of } \\
\text { coriander should be avoided. }\end{array}$ \\
\hline Damping-off & $\begin{array}{l}\text { Germination starts and seeds starts } \\
\text { rooting. Stem of soil gets weaker and it } \\
\text { looks in reddish colour.Contaminated } \\
\text { soil can spread fungi more faster in the } \\
\text { water. }\end{array}$ & $\begin{array}{l}\text { Plantation should be avoided in cool, } \\
\text { wet, and drainy soils. } \\
\text { Plantation should be done in raised } \\
\text { beds. High quality seeds should be } \\
\text { planted }\end{array}$ \\
\hline Powdery mildew & $\begin{array}{l}\text { Leaves,flowers and petiole gets } \\
\text { affected by powdery tissues.severe } \\
\text { infection can damage the flower.By the } \\
\text { means of air fungus can propagate to } \\
\text { longer distances.it reaches peak in high } \\
\text { humidity and moderate temperature.In } \\
\text { shaded areas infection looks more } \\
\text { severe. }\end{array}$ & $\begin{array}{l}\text { Plant high quality varities. excess } \\
\text { fertilization should be avoided. There } \\
\text { should be adequate protection provided } \\
\text { for the plants.in early season to avoid } \\
\text { infection sulphur can be used. }\end{array}$ \\
\hline
\end{tabular}

Loamy soils with well drained silt is mainly used for cultivation. The ph value should be 6-8 for the rain fed cultivaton. The $20-25^{\circ} \mathrm{C}$ is best temperature for coriander cultivation. necessary for coriander leaves .To prevent weed growth in coriander it needs well-drained sandy, loam soil and mulching of the soil is very important. For growing Coriander in ideal condition manure must be retained properly.to avoid soil moisture the plant should be ploughed 3-4 times before cultivation. The lands are ploughed two $r$ thrice for the irrigation crop. Heavy clay soil is not suitable

\section{FERTILIZING}

The fertilizers for growing coriander is very less. Adding to much fertilizer leads to the dilution of flavour of leaves and seeds. Phosphorous, Nitrogen and Potassium are mainly used as fertilizer in coriander leaves. Coriander use this three as the major fertilizers.

\section{DISEASES \& RESULTS} for coriander. 


\section{BASE PAPER}

\begin{tabular}{|c|c|c|c|}
\hline S.No & Title of the paper & Authors/year of publication & Highlights \\
\hline 1 & $\begin{array}{l}\text { Nutritional and medicinal } \\
\text { aspects of coriander } \\
\text { (Coriandrum sativum L.) }\end{array}$ & $\begin{array}{l}\text { Muhammad Nadeem, Faqir Muhammad } \\
\text { Anjum, Muhammad Issa Khan and Saima } \\
\text { Tehseen National Institute of Food Science and } \\
\text { Technology, University of Agriculture, } \\
\text { Faisalabad, Pakistan Ahmed El-Ghorab Food } \\
\text { Industry \& Nutrition Division, National } \\
\text { Research Center, Cairo, Egypt, and Javed Iqbal } \\
\text { Sultan Institute of Animal Nutrition and Feed } \\
\text { Technology, University of Agriculture, } \\
\text { Faisalabad, Pakistan }\end{array}$ & $\begin{array}{l}\text { This paper shows the } \\
\text { multiple functions of the } \\
\text { coriander plants the growth } \\
\text { the functionalities and yield } \\
\text { of coriander.it also says } \\
\text { about the nutritions and } \\
\text { spices which are present in } \\
\text { the plants.it also notes the } \\
\text { medicinal use of the } \\
\text { coriander. }\end{array}$ \\
\hline 2 & $\begin{array}{l}\text { Yield and Yield Contributes } \\
\text { of Coriander (Coriandrum } \\
\text { Sativum L.) as Influenced by } \\
\text { Spacing and Variety }\end{array}$ & $\begin{array}{l}\text { Abdul Kaium1, M. Islam1, S. Sultana2, E. } \\
\text { Hossain3, S.C.Shovon3, A.Mahjuba3 } \\
\text { 1Department of Agricultural Chemistry, Sher- } \\
\text { e-Bangla Agricultural University, Dhaka-1207 } \\
\text { 2Department of Soil Science, Sher-e-Bangla } \\
\text { Agricultural University, Dhaka-1207 } \\
\text { 3Department of Agricultural Botany, Sher-e- } \\
\text { Bangla Agricultural University, Dhaka-1207 }\end{array}$ & $\begin{array}{l}\text { In this paper the yield } \\
\text { estimation of the coriander } \\
\text { is mainly highlighted.here } \\
\text { the yield spacing which is } \\
\text { presented around the world } \\
\text { have been shown.the clear } \\
\text { view of showing } \\
\text { intercultural products has } \\
\text { been shown in this paper. }\end{array}$ \\
\hline 3 & $\begin{array}{ll}\text { "Agriculture Crop } & \text { Pattern } \\
\text { Using Data } & \text { Mining } \\
\text { Techniques" } & \end{array}$ & $\begin{array}{l}\text { G. Nasrin Fathima, "International Journal of } \\
\text { Advanced Research in Computer Science and } \\
\text { Software Engineering , Volume 4, Issue 5, } \\
\text { May } 2014 \text { ISSN: } 2277 \text { 128X". R.Geetha, }\end{array}$ & $\begin{array}{l}\text { This paper highlights the } \\
\text { crop patterns which are } \\
\text { present in the agriculture.it } \\
\text { also deals with the data } \\
\text { mining techniques which ar } \\
\text { e used in the agriculture } \\
\text { field. }\end{array}$ \\
\hline 4 & $\begin{array}{l}\text { "A Survey on Data Mining } \\
\text { Techniques in Agriculture" }\end{array}$ & $\begin{array}{l}\text { Ms.Kalpana,Dr.Shanthi,Dr.Arumugam, } \\
\text { "International Journal of Advances in } \\
\text { Computer Science and Technology, 3(8), } \\
\text { August 2014, 426-431 426". }\end{array}$ & $\begin{array}{l}\text { This paper shows the } \\
\text { techniques which are present } \\
\text { in the data mining.the usage } \\
\text { and methodology } \\
\text { functionality aspects needed } \\
\text { for the technique. }\end{array}$ \\
\hline 5 & $\begin{array}{l}\text { Clustering Analysis for } \\
\text { Appropriate Crop Prediction } \\
\text { using Hierarchical, Fuzzy C- } \\
\text { Means, K-Means and Model } \\
\text { based Techniques }\end{array}$ & $\begin{array}{l}\text { Dr Madhavi Gudavalli1, Vidyasree P2, S } \\
\text { Viswanadha Raju, International Journal of } \\
\text { Advance Engineering and Research } \\
\text { Development Volume 4, Issue 11, November - } \\
2017\end{array}$ & $\begin{array}{l}\text { This paper show about the } \\
\text { data sets and clusters which } \\
\text { are presented in data mining } \\
\text { and display the procedure } \\
\text { and rules followed for } \mathrm{k} \\
\text { means clustering algorithm. }\end{array}$ \\
\hline
\end{tabular}

\section{CONCLUSION}

The crop yield estimation in data mining is the real time problem faced by the farmers. The yield estimation of coriander leaves is calculated using data mining algorithm. The specified data mining algorithm used here is $\mathrm{k}$ means clustering. The problem defined here is climate and fertility of the soil. By knowing the suitable climate and fertility of soil coriander leaves can be grown in all season with the help of data set which can be calculated using data mining algorithm. In future the area can be increased from small scale to large scale.

\section{FUTURE SCOPE}

In future the data mining algorithm will be written for this paper. Using the data mining algorithm the data set for the growth of banana plants can be calculated. More modules for this paper will be added and finally it will be implemented in a website.

\section{REFERENCES:}

1 G. Nasrin Fathima, R.Geetha, "Agriculture Crop Pattern Using Data Mining Techniques", "International Journal of Advanced Research in Computer Science and Software Engineering, Volume 4, Issue 5, May 2014 ISSN: 2277 128X".

2 Hetal Patel, Dharmendra Patel, "A Brief survey of Data Mining Techniques Applied to Agricultural Data", "International Journal of Computer Applications (0975 8887) Volume 95- No. 9, June 2014".

3 Ms.Kalpana,Dr.Shanthi,Dr.Arumugam, "A Survey on Data Mining Techniques in Agriculture", "International Journal of Advances in Computer Science and Technology, 3(8), August 2014, 426 - 431 426”.

4 Ramesh A, Vijay. S. Rajpurohit, " A survey on Data Mining Techniques for Crop Yield Prediction", "International Journal of Advance Research in Volume 2, Issue 9, September 2014". 
5 Surabhi Chouhan ,Divakar Singh, Anju Singh, “A Survey and Analysis of Various Agricultural Crops Classification Techniques", "International Journal of Computer Applications (0975 - 8887) Volume 136 No.11, February 2016 25".

6 Perpetua Noronha, Divya .J, Shruthi .B.S, "Comparative Study of Data Mining Techniques in Crop Yield Prediction ", “ International Journal of Advanced Research in Computer and Communication Engineering, Vol. 5, Special Issue 2, October 2016 “.

7 Dhivya BH, Manjula R, Siva Bharathi S, Madhumathi R, "A Survey on Crop Yield Prediction based on Agricultural Data", "International Journal of Innovative Research in Science, Engineering and Technology (An ISO 3297: 2007 Certified Organization), Vol. 6, Issue 3, March 2017".

8 G R Batts, "Effects Of CO2 And Temperature on Growth and Yield of Crops of Winter Wheat over Four Seasons", European Journal of Agronomy, vol. 7, 1997, pages : 4352.

9 Meyer G E, Neto J C, Jones D D, Hindman T W, "Intensified Fuzzy Clusters for Classifying Plant, Soil and Residue Regions of Interest from Color Images". Computer Electronics Agric Vol. 42, 2004, pages : 161180

10 R J Brooks, "Simplifying Sirus : Sensitivity Analysis and Development of A Meta-Model for Wheat Yield Prediction", European Journal of Agronomy, vol. 14, 2001, pages : 43-60. 